\title{
Crop yield bienniality in groups of genotypes of conilon coffee
}

\author{
Wagner Nunes Rodrigues ${ }^{1 \star}$, Marcelo Antonio Tomaz ${ }^{2}$, Romário Gava Ferrão ${ }^{3}$, \\ Maria Amélia Gava Ferrão ${ }^{4}$, Aymbiré Francisco Almeida da Fonseca ${ }^{4}$ and \\ Lima Deleon Martins ${ }^{1}$
}

${ }^{1}$ Programa de Pós-Graduação em Produção Vegetal, Centro de Ciências Agrárias da Universidade Federal do Espírito
Santo, CCA-UFES, Alto Universitário, Cx. P. 16, CEP: 29500-000, Alegre, Espírito Santo, Brazil.
²Departamento de Produção Vegetal, Centro de Ciências Agrárias da Universidade Federal do Espírito Santo,
CCA-UFES, Alto Universitário, Cx. P. 16, CEP: 29500-000, Alegre, Espírito Santo, Brazil.
${ }^{3}$ Instituto Capixaba de Pesquisa, Assistência Técnica e Extensão Rural, INCAPER, Rua Afonso Sarlo, 160,
Bento Fereira, CEP: 29052-010, Vitória, Espírito Santo, Brazil.
${ }^{4}$ Empresa Brasileira de Pesquisa Agropecuária, EMBRAPA CAFÉ/INCAPER, Parque Estação Biológica, PqEB, s/n, CEP: 70770-901, Brasília, Brazil.

Accepted 21 August, 2013

\begin{abstract}
Coffee plantations present large spatial and temporal variability of yield, the variation along the years with high and low productions is known as bienniality. This study investigated the bienniality in different groups of genotypes of conilon coffee, classified by the ripening cycle, evaluating the crop yield of the clones along four years to determine the magnitude of the bienniality. The results indicate that, the bienniality is present in genotypes of conilon coffee from all the studied groups of genotypes, existing very biennial genotypes and also very stable genotypes within each group.
\end{abstract}

Key words: Coffea canephora, crop yield, stability.

\section{INTRODUCTION}

Coffee is one of the most valuable traded commodities in the world. The species Coffea canephora is the most widely grown in the State of Espírito Santo. In addition, this state is the largest Brazilian producer of conilon coffee, with approximately an estimated production of 9.25000000 bags for 2013. The coffee park in Espírito Santo covers an area of approximately 280000 ha in current production, with an average crop yield of 34.68 bags per hectare (Conab, 2013).

A large spatial and temporal variability occurs in the crop yield of coffee plantations, being common in the occurrence of plants with low production alongside with highly productive plants. The temporal variability, such as the bienniality, results in years with high yield intercalated with years of low production (Carvalho et al., 2004).

The bienniality is a phenomenon more pronounced in the species $C$. arabica, but it is also present in $C$. canephora, usually less intense due its mitigation with the pruning practices and alternation of the plagiotropic branches in production. This biennial alternation of yield is the result of the physiological nature of the coffee plant, which needs to vegetate along a year to sustain the fruit production in the next year (Rena and Maestri, 1985).

The occurrence of bienniality in coffee plants is connected to a source-sink relationship existing between fruit and leaves. Leaves are sources of photosynthates while the growing tissues act as sinks. As both of the reproductive and vegetative growths occur simultaneously, 
the plant needs to balance the partition of photosynthates for both processes (Barros, 1997).

In years of high production, the plant directs the photosynthates to the formation and growth of fruits, reducing the formation of new vegetative buds. In years of low production, the photosynthates are directed to the formation of new vegetative buds that will produce new branches. Therefore, the over production of fruits in a year causes a reduction in growth in the current year, exhausting the metabolic reserves for the fruit production. Consequently, the growth is restricted and the emission of new plagiotropic branches is limited, compromising the fruit production of the next season (Picini, 1998).

Due to the socio-economic importance of coffee in Brazil, the Instituto Capixaba de Pesquisa Assistência Técnica e Extensão Rural (INCAPER), since 1985, has been developing a breeding program to improve the conilon coffee in the Espírito Santo State, providing new cultivars adapted to its conditions (Ferrão et al., 2007a). The genotypes that have been developed and evaluated by the said program present diversity for a series of agronomic characteristics, and are classified primarily through its maturation cycles which allows the differentiation and classification of genotypes in groups of early, intermediate and late ripening cycle, according to the period of time required for the complete maturation. This study investigated the bienniality of yield in groups of genotypes of conilon coffee classified by the ripening cycle.

\section{MATERIALS AND METHODS}

The experiment consisted of three assays, all conducted at the Bananal do Norte Experimental Farm led by INCAPER in the municipality of Cachoeiro de Itapemirim located at $20^{\circ} 45^{\prime} S$ and $41^{\circ} 17^{\prime} \mathrm{W}$, Pacotuba district in the southern State of Espírito Santo. This region presents annual rainfall near $1,200 \mathrm{~mm}$ and an annual temperature around $23^{\circ} \mathrm{C}$; its climate is classified as Cwa (wet summer and dry winter) according to the Kopen classification. The altitude is $140 \mathrm{~m}$ and the topography is wavy-rugged. The soil is classified as a dystrophic oxisol.

Each assay was conducted following an experimental design in randomized blocks, with 4 replications and 5 plants per plot:

(i) Assay I evaluated the yield bienniality in a group of 20 genotypes of early ripening cycle: NP01, NP02, NP03, NP04, NP05, NP06, NP07, NP08, NP09, NP10, NP11, NP12, NP13, NP14, NP15, NP16, NP17, NP18, NP19, and NP20,

(ii) Assay II studied 20 genotypes classified in the group of intermediate cycle: NI01, NI02, NI03, NI04, NI05, NI06, NI07, NI08, NI09, NI10, NI11, NI12, NI13, NI14, NI15, NI16, NI17, NI18, NI19, and $\mathrm{NI20}$,

(iii) Assay III evaluated 20 genotypes of late cycle: NT01, NT02, NT03, NT04, NT05, NT06, NT07, NT08, NT09, NT10, NT11, NT12, NT13, NT14, NT15, NT16, NT17, NT18, NT19, and NT20; all classified according to the time required to complete the fruit maturation (Bragança et al., 1993; 2001).

The genotypes were asexually multiplied through cutting and cultivated in competition fields since 2004, with spacing of $3.00 \times$ $1.20 \mathrm{~m}$, and conducted until the beginning of the production cycle.
The plantation management was performed according to the current recommendation for conilon coffee in the Espírito Santo State (Ferrão et al., 2007b; Lani et al., 2007; Prezotti et al., 2007).

From 2006, evaluations of the crop yield were initiated to establish the yield oscillation of each genotype until the 2009 harvest. The extent of this oscillation was mathematically measured by the method proposed by Stevens (1949) who studied coffee varieties suggested that, the magnitude of the bienniality could be measured by subtracting the mean production of the years of low production from the mean of the years of high production based on an even number of years.

The data were subjected to variance analysis by the test $F$ ( $p \leq$ 0.05 ), and according to the significance of the genotype effect, the means were compared using the criteria of Scott-Knott $(p \leq 0.05)$. The genetic parameters were estimated based on the variance analysis to study the influence of genetic and environmental factors over the bienniality. All the procedures were made using the statistical software GENES (Cruz, 2006).

\section{RESULTS AND DISCUSSION}

After evaluating the yield of each genotype within each assay, the biennial cycle of high and low fruit production was established. According to Picini et al. (1999), the coffee yield is highly dependent on the productivity of the previous year and particularly sensitive to water stress during the period between the end of bud dormancy and the flowering, as well as between the final stage of flowering and the early grain formation. Therefore, the variations observed in the behavior of different genotypes may be due to the effect of weather conditions in each season, associated with the productive capacity of each genetic material, their resilience, and their fruit load.

The analysis of variance proved the significance of the effect of genotypes in all the 3 assays, indicating the presence of variability within each group of genotypes. Overall means of bienniality around 30 bags per hectare (bags ha ${ }^{-1}$ ) were observed and the coefficients of variation were acceptable for experimentation in perennial crops.

The comparison between genotypes identified 5 groups of homogeneous means for bienniality in Assays I and II, and 2 groups in Assay III. While some genotypes presented a stable cycle of production over the seasons, with variation of only 4.39 bags ha-1, others had highly biennial yield, presenting variation ranging up to 88.14 bags ha ${ }^{-1}$ (Table 1 ).

In Assay I, the genotypes NP13 and NP14 were the most biennials, with the highest means for variation of production between harvests with 71.81 and 70.79 bags $\mathrm{ha}^{-1}$, respectively. The genotype NP18 formed alone, the second group of means with 43.92 bags $\mathrm{ha}^{-1}$. The genotypes NP08 and NP01 were allocated in the third group of homogeneous means, with bienniality near to 30 bags $\mathrm{ha}^{-1}$. The fourth group presented bienniality between 18.77 and 4.39 bags ha $^{-1}$ and consisted of the genotypes NP07, NP16, NP17, NP11, and NP20. The genotypes of the early ripening group that presented lower yield oscillation were NP10, NP03, NP15, NP12, 
Table 1. Genotypic square mean $\left(\mathrm{SM}_{\mathrm{g}}\right)$, descriptive analyses, coefficient of variation $(\mathrm{CV})$, phenotypic variation $\left(\widehat{\sigma}_{\mathrm{f}}\right)$, environmental variation $\left(\widehat{\sigma}_{\mathrm{e}}\right)$, genotypic variation $\left(\widehat{\Phi}_{\mathrm{g}}\right)$, coefficient of genotypic determination $\left(\mathrm{H}^{2}\right)$, coefficient of genotypic variation $\left(\mathrm{CV}_{\mathrm{g}}\right)$ and variation index $\left(\mathrm{CV}_{\mathrm{g}} / \mathrm{CV}\right)$ for bienniality (bag ha $\left.{ }^{-1}\right)$ of genotypes of conilon coffee, from different groups, classified according to the ripening cycle, at Bananal do Norte Experimental Farm/INCAPER.

\begin{tabular}{|c|c|c|c|}
\hline Parameter & $\begin{array}{l}\text { Assay I } \\
\text { Early }^{1}\end{array}$ & $\begin{array}{c}\text { Assay II } \\
\text { Intermediate }\end{array}$ & $\begin{array}{c}\text { Assay III } \\
\text { Late }^{3}\end{array}$ \\
\hline $\mathrm{SM}_{\mathrm{g}}$ & $1384.62^{\star *}$ & $1699.65^{\star *}$ & $816.29^{* *}$ \\
\hline Maximum (bag ha ${ }^{-1}$ ) & 92.06 & 98.67 & 74.37 \\
\hline Overall mean (bag ha ${ }^{-1}$ ) & 24.85 & 31.82 & 31.30 \\
\hline Minimum (bag ha $\left.{ }^{-1}\right)$ & 3.20 & 6.69 & 5.17 \\
\hline CV (\%) & 24.44 & 19.90 & 23.17 \\
\hline$\widehat{\sigma}_{f}$ & 346.15 & 424.91 & 204.07 \\
\hline$\widehat{\sigma}_{\mathrm{e}}$ & 9.22 & 10.03 & 13.15 \\
\hline$\widehat{\phi}_{\mathrm{g}}$ & 336.92 & 414.87 & 190.91 \\
\hline $\mathrm{H}^{2}(\%)$ & 97.33 & 97.63 & 93.55 \\
\hline $\mathrm{CV}_{\mathrm{g}}(\%)$ & 73.84 & 64.00 & 44.13 \\
\hline $\mathrm{CV}_{\mathrm{g}} / \mathrm{CV}$ & 3.02 & 3.21 & 1.90 \\
\hline
\end{tabular}

\begin{tabular}{|c|c|c|c|c|c|}
\hline Genotype & Mean & Genotype & Mean & Genotype & Mean \\
\hline NP13 & $71.81^{a}$ & $\mathrm{~N} 111$ & $88.14^{a}$ & NT02 & $61.34^{a}$ \\
\hline NP14 & $70.79^{a}$ & NI06 & $60.89^{b}$ & NT19 & $52.01^{a}$ \\
\hline NP18 & $43.92^{b}$ & $\mathrm{NIO3}$ & $50.66^{c}$ & NT08 & $46.27^{b}$ \\
\hline NP08 & $35.50^{c}$ & $\mathrm{~N} I 14$ & $46.93^{\mathrm{C}}$ & NT20 & $45.76^{b}$ \\
\hline NP01 & $35.29^{c}$ & $\mathrm{~N} 120$ & $46.93^{c}$ & NT03 & $42.81^{b}$ \\
\hline NP07 & $23.10^{d}$ & $\mathrm{~N} 113$ & $42.12^{c}$ & NT06 & $40.85^{b}$ \\
\hline NP16 & $23.07^{d}$ & $\mathrm{NI02}$ & $42.09^{c}$ & NT01 & $39.71^{b}$ \\
\hline NP17 & $22.77^{d}$ & NI18 & $39.83^{c}$ & NT11 & $36.52^{b}$ \\
\hline NP11 & $22.62^{d}$ & NI08 & $39.59^{c}$ & NT13 & $33.06^{c}$ \\
\hline NP20 & $20.91^{d}$ & NI05 & $25.03^{d}$ & NT05 & $29.72^{C}$ \\
\hline NP10 & $18.77^{\mathrm{e}}$ & $\mathrm{N} / 15$ & $24.19^{d}$ & NT16 & $29.45^{c}$ \\
\hline NP03 & $17.90^{\mathrm{e}}$ & $\mathrm{N} / 12$ & $18.86^{d}$ & NT14 & $27.80^{\mathrm{C}}$ \\
\hline NP15 & $16.06^{\mathrm{e}}$ & $\mathrm{N} 117$ & $17.69^{d}$ & NT15 & $25.99^{c}$ \\
\hline NP12 & $13.81^{\mathrm{e}}$ & $\mathrm{N} I 19$ & $17.42^{d}$ & NT10 & $24.13^{c}$ \\
\hline NP05 & $13.78^{\mathrm{e}}$ & NI16 & $16.00^{\mathrm{e}}$ & NT09 & $22.23^{\mathrm{C}}$ \\
\hline NP06 & $13.33^{\mathrm{e}}$ & $\mathrm{N} / 10$ & $13.54^{\mathrm{e}}$ & NT07 & $17.15^{\mathrm{d}}$ \\
\hline NP04 & $11.10^{\mathrm{e}}$ & NI09 & $13.33^{\mathrm{e}}$ & NT12 & $16.12^{d}$ \\
\hline NP19 & $9.84^{e}$ & NI07 & $12.64^{\mathrm{e}}$ & NT17 & $15.25^{\mathrm{d}}$ \\
\hline NP02 & $8.36^{\mathrm{e}}$ & $\mathrm{NIO4}$ & $12.18^{\mathrm{e}}$ & NT18 & $12.51^{d}$ \\
\hline NP09 & $4.39^{\mathrm{e}}$ & NI01 & $8.39^{\mathrm{e}}$ & NT04 & $7.49^{d}$ \\
\hline
\end{tabular}

**Significant at $1 \%$ of probability by the $\mathrm{F}$ test. Means followed by the same letter do not differ statistically from each other, by the ScottKnott criteria, at $5 \%$ of probability; ${ }^{[1]}$ Group of genotypes with ripening cycle completed in 34 weeks; ${ }^{[2]}$ Group of genotypes with ripening cycle completed in 41 weeks; ${ }^{[3]}$ Group of genotypes with ripening cycle completed in 45 weeks.

NP05, NP06, NP04, NP19, NP02, and NP09 (Figure 1A). In Assay II, the highest bienniality mean came from the genotype NI11, which presented a wide yield variation, reaching 88.14 bags $\mathrm{ha}^{-1}$, followed by the genotype NI06 with 60.89 bags ha $^{-1}$, which, alone, formed the second group of homogeneous means. The next group was formed by the genotypes $\mathrm{NI03}, \mathrm{Nl} 14, \mathrm{NI} 20, \mathrm{NI} 13, \mathrm{NIO2}$, NI18, and NI08, which reached bienniality means between 50.66 and 39.59 bags ha $^{-1}$. The fourth group showed means between 25.03 and 17.42 bags $\mathrm{ha}^{-1}$, being formed by the genotypes NI05, NI15, NI12, NI17, and NI19. The other genotypes (NI16, NI10, NI09, NI07, NI04, and NI01) had means lower than 16.00 bags ha ${ }^{-1}$, with less effect of bienniality and greater yield stability along the harvests (Figure 1B).

In Assay III, the genotypes NT02 and NT19 were the most biennial, with means of 61.34 and 52.01 bags ha ${ }^{-1}$, respectively. A second group of similar means was 

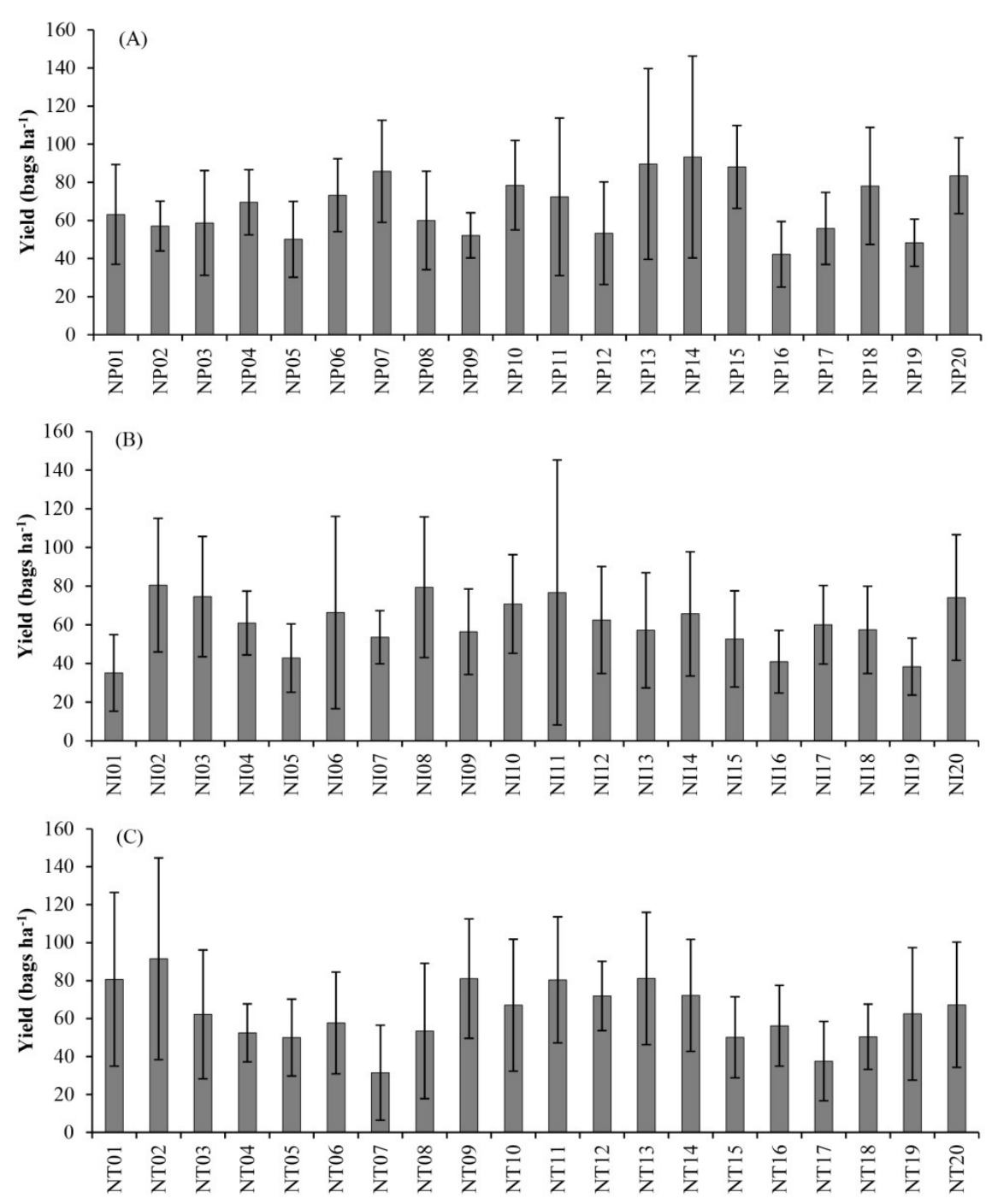

Figure 1. Means and standard deviations for crop yield in genotypes of conilon coffee from 3 groups classified according to the ripenning cycle: early $(A)$, intermediate $(B)$ and late $(\mathrm{C})$, at the Bananal do Norte Experimental Farm/ INCAPER.

formed by the genotypes NT08, NT20, NT03, NT06, NT01, and NT11, with bienniality means from 46.27 to 36.52 bags ha $^{-1}$. The genotypes NT13, NT05, NT16, NT14, NT15, NT10, and NT09 were placed in the third group, which was between 33.06 and 22.23 bags ha $^{-1}$ of bienniality. The genotypes NT07, NT12, NT17, NT18, and NT04 formed the group of lowest means, with greater yield stability over the seasons than others (Figure 1C).

The genetic parameters (Table 1) indicate that, bienniality of coffee yield may be related to a characteristic of the genetic material itself, being expressed in greater magnitude when adverse environmental conditions cause stress to the plants. As result of those conditions, the plants may not be able to recover themselves at a sufficient rate so that, the production of fruits in the following year is not affected.
Therefore, the biennial genotypes possibly are more sensitive to the effects of stress, such as prolonged periods of drought, the occurrence of diseases or pests attacks, or even the metabolic stress caused by a high fruit load.

After the identification of the genotypes that are most affected by the phenomenon of bienniality, it become possible to adopt management techniques that reduce its effect. The effect of bienniality can be affected by the irrigation management; the volume of water supplied can determine the productivity and stability throughout the productive cycle of the coffee plants. The plantation density can also cause a reduction in the biennial cycle of production, by inducing a lower yield per plant which provides less metabolic stress (Matiello et al., 2002). For C. canephora which is normally conducted with multiple orthotropic branches per plant, the pruning system also 
mitigates the effects of this yield variation over time.

\section{Conclusion}

The yield bienniality is present in genotypes of conilon coffee from all groups of ripening cycle studied in this work, as well as existing genotypes with high bienniality and genotypes with stable production along the harvests.

The bienniality is a characteristic highly associated with the genetic material itself, being expressed in greater magnitude when adverse environmental conditions cause stress to the plants.

The genotypes NP10, NP03, NP15, NP12, NP05, NP06, NP04, NP19, NP02, and NP09 from the group of early ripening cycle; NI16, NI10, NI09, NI07, NI04, and NI01 from the group of intermediate cycle; and the genotypes NT07, NT12, NT17, NT18, and NT04 from the group of late cycle present lower yield bienniality.

The genotypes NP13, NP14 (Assay I), NI11 (Assay II), NT02 and NT19 (Assay III) show wide variation in the yield along the time, being considered as biennial materials.

\section{REFERENCES}

Barros I (1997). Produção das variedades Caturra e Mundo Novo de café em função do espaçamento, número de plantas por cova e condução das plantas. Dissertação de mestrado. Escola Superior de Agricultura "Luiz de Queiroz". Piracicaba P. 82.

Bragança SM, Carvalho CHS, Fonseca AFA, Ferrão RG, Silveira JSM (1993). 'Emcapa 8111', 'Emcapa 8121', 'Emcapa 8131': primeiras variedades clonais de café Conilon lançadas para o Espírito Santo. Vitória, EMCAPA. P. 2.

Bragança SM, Carvalho CHS, Fonseca AFA, Ferrão RG (2001). Variedades clonais de café Conilon para o Estado do Espírito Santo. Pesquisa Agropecuária Brasileira 36:765-770.

Carvalho LG, Sediyama GC, Cecon PR, Alves HMR (2004). A regression model to predict coffee productivity in Southern Minas Gerais, Brazil. Revista Brasileira de Engenharia Agrícola e Ambiental 8:204-211.
Conab - Companhia Nacional de Abastecimento (2013). Acompanhamento da safra brasileira de café: Safra 2013, segunda estimativa, maio/2013. Brasília, CONAB. P. 18.

Cruz CD (2006). Programa GENES: estatística experimental e matrizes. Viçosa, UFV. P. 285.

Ferrão RG, Fonseca AFA, Ferrão MAG, De Muner LH, Verdin Filho AC, Volpi PS, Marques EMG, Zucateli F (2007a). Café conilon: Técnicas de produção com variedades melhoradas. 3rd ed. Vitória, Incaper. P. 60.

Ferrão RG, Fonseca AFA, Bragança SM, Ferrão MAG, De Muner LH (2007b). Café Conilon. Vitória, Incaper. P. 702.

Lani JA, Prezotti LC, Bragança SM (2007). Cafeeiro. In: Prezotti LC, Gomes JA, Dadalto GG and Oliveira JA. Manual de recomendação de calagem e adubação para o Estado do Espírito Santo: 5 aproximação. Vitória, SEEA/INCAPER/CEDAGRO. pp. 111-118.

Matiello JB, Santinato R, Garcia AWR, Almeida SR, Fernandes DR (2002). Cultura do café no Brasil: novo manual de recomendações. Rio de Janeiro, MAPA. P. 387.

Picini AG (1998). Desenvolvimento e teste de modelos agrometeorológicos para estimativa de produtividade do cafeeiro (Coffea arabica L.) a partir do monitoramento da disponibilidade hídrica do solo. Dissertação de Mestrado. Escola Superior de Agricultura "Luiz de Queiroz". Piracicaba P. 132.

Picini AG, Camargo MBP, Fazuoli LC, Gallo PB, Ortoloni AA (1999). Desempenho de modelo matemático agro-meteorológico de estimativa de produtividade para a cultura do café no Estado de São Paulo. In: $11^{\circ}$ Congresso Brasileiro de Agrometeorologia e $2^{\mathrm{a}}$ Reunião Latino-Americana de Agrometeorologia, Florianópolis. Anais, SBA. pp. 542-548.

Prezotti LC, Gomes JA, Dadalto GG, Oliveira JA (2007). Manual de recomendação de calagem e adubação para o Estado do Espírito Santo: 5ª aproximação. Vitória, SEEA/INCAPER/CEDAGRO. P. 305.

Rena AB, Maestri M (1985). Fisiologia do cafeeiro. Informe Agropecuário 11:26-40.

Stevens WL (1949). Analises estatísticas do ensaio de variedades de café. Bragantia 9:103-123. 